\title{
Discourse and Commodified Identities Construction: Case Studies of Iranian EFL Learners and Teachers at Private Language Schools
}

\author{
Azar Hosseini Fatemi ${ }^{1}$, Reza Pishghadam ${ }^{1} \&$ Seyyed Mohammad Reza Adel ${ }^{1, *}$ \\ ${ }^{1}$ English Department, Ferdowsi University of Mashhad, Mashhad, Iran \\ *Corresponding author: English Department, Ferdowsi University, Mashhad, Park Square, PO box 9177948974, Iran \\ E-mail: adelzero@yahoo.co.uk
}

Received: September 24, 2012 Accepted: November 8, 2012 Online Published: December 12, 2012

doi:10.5430/wjel.v2n4p32

URL: http://dx.doi.org/10.5430/wjel.v2n4p32

\begin{abstract}
The purpose of this cultural study was the analysis of commodified identities construction in an EFL context. Our site of struggle for the analysis was a private institution and the related variables were English textbooks, six teachers and six learners as our cases. Our whole data collection took from 23 September 2010 to 30 September 2011. Our theoretical framework was inspired by constructivism and in particular Bakhtin's dialogism and we followed an ethnographic methodology in our data collection. The results of the content analysis of the textbooks, teachers and learners' data showed the existence and construction of commodified identities, though there were intra and inter variations among the teachers' responses regarding commodified identities. The results were discussed in connection with the context of language teaching and some pedagogical implications were also suggested.
\end{abstract}

Keywords: Commodified identities construction; Dialogism; Private schools; Textbooks; Learners; Teachers

\section{Introduction}

In the present study, we have tried to investigate the role of commodified identities construction in an EFL situation through a case study. Constructivism in general and dialogism in particular are our theoretical frameworks. We have probed the role of commodified identities construction in a private school with six learners and six teachers. Therefore, in what follows, we try to give a brief review of our theoretical paradigm and related concepts and then pose our related research questions for that matter.

\section{Literature Review}

Broadly speaking, there are two perspectives or paradigm shifts in the history of identity. On the one hand, it has been treated as an essential or cognitive phenomenon that governs human action, and on the other hand, it has been considered as a public phenomenon, a performance or construction that is interpreted by other people. The shift has been a move from essentialism to constructionism or social constructivism; in other words from analyzing linguistic identity as a given and fixed aspect of who an individual or group is, to something changeable and variable as it is constructed and performed.

Essentialism means 'the assumption that groups, categories or classes of objects have one or several defining features exclusive to all members of that category' (Ashcroft, Griffiths \& Tiffin, 2000, p.77). In constructionism, the subject assumes different identities at different time. Within us are differing identities, pulling in different directions so that our identifications are continuously being modified. 'We are confronted by a bewildering, fleeting multiplicity of possible identities, any one of which we could identify with - at least temporarily' (Hall, 1992, p. 277). In the present study we have discussed commodified identities as one type of identities from the perspective of dialogism theory of Bakhtin which is constructivist. Among the very core concepts of dialogism, two important concepts, which are related to our study, are discussed briefly.

For Bakhtin a word is a world. He declares that, 'an individual's becoming, an ideological process, is characterized precisely by a sharp gap between ... the authoritative word (religious, political, moral; the word of a father, of adults and of teachers, etc.) that does not know internal persuasiveness, and . . . the internally persuasive word that is denied all privilege, backed up by no authority at all, and is frequently not even acknowledge in society' 
(Bakhtin, 1981, p. 342). Unlike dialogic language, 'the authoritative word or discourse is monologic, distant from context, unanswerable, and embodies different sources of authority (tradition, generally accepted truths, official lines). It is an imposition, in the sense that it demands that we acknowledge it, that we make it our own; it binds us quite independent of any power it might have to persuade us internally; we encounter it with its authority already fused into it. The authoritative word is located in a distanced zone, organically connected with a past that is felt to be hierarchically higher. . . . It is therefore not a question of choosing it from among other possible discourses that are its equal' (p. 342). In the words of Holquist, 'undialogized language is authoritative or absolute' (1981, p. 426-7). Authoritative discourses or what Delpit (1995), Gee $(1996,2011)$, and others have termed 'the languages of power' encode 'cultural capital' (Bordieu \& Passeron, 1977). Now, based on such grounds, identities, and commodified identities in particular, may be projected authoritatively or suggested persuasively.

No one can readily deny the influence of consumerism in today's society. This, of course, has had varying degrees of effects on different groups of people with regard to gender, race, etc. Some scholars have fairly interesting ideas about consumerism in our life. According to Giddens (1991), consumerism is the major feature of what critics have called post-industrial 'late modernity'. Featherstone (1991) believes that consumption is a highly important feature of postmodern society. Even some groups of scholars have expressed negative attitudes towards consumerism as 'an all-developing force to which, increasingly, all identities are subject - a force which dictates that anything is potential substance for consumption, even ourselves' (Benwell \& Stokou, 2006). In addition to this last comment, several others have tried to emphasize the influence of consumerism on the consumers' identities.

Of course, there have been a wide variety of theories about how consumerism and identity are connected, especially during the last few decades (Cindy, Jonah, \& Leaf, 2012; Hamouda, 2012; Zeynep \& Craig, 2011) Nearly all of these theories emphasize the close relationship between people's identity and consumption. Therefore, this extremely important process of commodification in our post-modern society shows that more detailed researches are needed to investigate into the relationship between consumption and identity, particularly its connection with the language teaching and learning context.

According to Campbell (1987), consumerism was first proposed in the eighteenth century, mostly influenced by the rise of the Roman individualism. The basic principle of this perspective is that we consume according to who we are or want to be and everything is directed to the advantage of the individual (Corrigan, 1997). As a result, consumption creates a sense of identity; in other words, consumption helps us feel distinct from others. Little by little, particular goods or forms of consumption indicate people's membership to certain social or cultural groups or distinguish between male and females or other differences. Veblen (1899) was among the same group of scholars who regarded consumption as 'a key means of achieving social differentiation and thus status'. He even coined a new term in consumerism called 'conspicuous consumption'. Another related concept in this area was proposed by Bourdieu (1984). He used the concept 'cultural capital' 'to describe the way in which different classes use different goods and consumption practices in order to situate themselves in social space'.

Douglas and Isherwood (1979) also described how people used goods to create an intelligible culture and establish and sustain social relations. To do so, they examined consumption from an anthropological point of view. They believed that in this process both the promotion of special products and the acquisition of the skills, concepts or practical knowledge about how to use these products are very important (Talbot 1995). Having worked on 'neo-tribes', Bauman (1993) concluded that consumption is a highly important factor in people's identities. He maintained that the way people consume different things distinguish them from the members of other social groups. In this research, it was strongly believed that interpersonal constraints have a remarkable influence on identities created through consumption. Baudrillard (1998) believed that the relationship between identity and consumption is much closer. He argued that 'we become what we consume'. In other words, on the basis of postmodern theories, cultural consumption is regarded as the source or material out of which our identities are created. According to this point of view, people shape their identity through buying particular goods and special articles. According to Baudrillard, commodities and objects, rather like words, constitute a system of signs (cf. de Saussure 1960) - a system that substitutes needs and pleasures for values and classifications. The 'sign value' of objects replaces the use value of objects: commodities achieve meaning, not because they are really useful, but because they are related to a whole system of signs. Baudrillard (1998, p. 61) also regards consumption as a way to show differentiation.

Baudrillard's viewpoint on consumption is undoubtedly negative because he gives little control to consumers. According to him, consumers are socialized into a system that is to a large extent beyond their control. In addition, Gidden (1991) proposed a notion called 'the commodification of the self'. He claims that consumers are perfectly under the influence of consumption force and even try to distinguish themselves by choosing a certain product. 
This negative attitude towards the concept of commodification and consumption is greatly influenced by a particular school of theory called the Frankfurt School. According to the Frankfurt School of theory, mass culture is really criticized and a new notion called 'culture industries' is proposed. The proponents of this model believed that consumers are like passive dupes, greatly influenced by the production and advertising of the 'false needs', created by what producers decide as important or useful. In addition, since consumer culture tries to appeal to a large group of people, it is regarded as inauthentic and homogenizing. Fairclough (1992) also believes that commodification creates a kind of uncertainty about what is really promotional and authentic and as a result establishes a close relationship between self-promotion and self-identity.

During the recent years, however, there have been some researches attesting to this fact that in some situations there are few, if any, opportunities available to individuals about resistance to commodification of something. In other words, these scholars believe that sometimes the situations impose the consumption of certain products on consumers. For example, Tan (1978), discussing the commodification of the English language by focusing on the current official debates and comments, concluded that 'the debate in Malaysia is certainly indicative of the prevalence of the discourse of economic commodification and globalization to the exclusion of other kinds of discourse'. He believed that Malaysian people are repeatedly told that many job positions in Malaysia are empty since job applicants do not have the required proficiency in English and that English is closely connected with achieving success in global communication with foreigners. In these debates, Malaysians are not as free as they should be whether to learn English or not.

In a similar vein, Singh and Han (1988) maintained that the internationalization of education increased the commodity value of English; this has been greatly emphasized since at least the 18th century. They believed that English is not just product or service to make money, but also it is an indispensable way to facilitate or expedite the exchange of the knowledge; a concept which is crucial to achieving success in the 'new' economy (Wächter, 2004). So in one way or another, people who want to be successful have to learn this language and the consumers have no other choice here.

Bowers (2000), explaining the numerous advantages of new technologies in education, believed that students and universities have no other choice but to turn into good customers for these commodities advertised by different companies. He believed that if they want to resist this situation, they will fall behind.

All scholars, however, are not so gloomy about the role of consumers in commodification discourses. Relatively recent theories and models within cultural studies appreciate the active role of the consumer. The proponents of these theories believe that identity is not something which can be easily suggested or influenced. Keat, Whitely and Abercrombie (1994), proposing the notion of 'authority of the consumer', attach much more importance to consumers' roles and Fiske (1989) emphasizes that consumers are 'cultural experts'. He chooses this term to say that consumers are really critical and creative while they are faced with a wide variety of products or goods. Frost (2010) also argues that 'consumers in the early twenty-first century are more aware of the commercial environment they inhabit than they have been before. As such, they are more comfortable in engaging or rejecting consumption activities than many critics are willing to grant' (p. 58). Therefore, the major implication of these models is that consumers are constantly active in the process of consumption or the formulation of their commodified identities. The advocates of previous models, of course, have expressed doubts about the highly and extremely active roles assigned to consumers in the process of consumption by these new theories or models. However, recent experimental or case studies show that consumers are not as passive as they were regarded by previous models.

Moreover, some regard consumers as the mere subjects of the consumption process and some assign more active roles to them. Mills (1998, p. 147) uses the term 'the consuming paradox' to show these differences. However, what seems more reasonable is that in daily life situations a combination of these should be considered. As mentioned earlier, sometimes the constraints or limitations of the situation give consumers no options to behave differently, but sometimes consumers actively compare different products and adopt the most appropriate ones. In this study, we try to consider the commodified identities of foreign language learners influenced by their textbooks, their teachers, and their own choice. In line with the theories mentioned, our research questions are divided into three categories of textbook, teacher and learner's questions:

A. Textbook related questions:

1) Are there any commodified identities (cultural topics, cultural names, and cultural activities) presented in the learners' textbooks? 
2) What are the special discourse types associated with the cultural commodified identities in the learners' textbooks?

3) How are commodified cultural identities represented in the learners' textbooks?

B. Teacher related questions:

1) Are private English language teachers influenced by commodified identities?

2) How are commodified identities promoted by private English language teachers?

3) Are commodified identities suggested persuasively or projected authoritatively by private English language teachers?

C. Learner related questions:

1) Are private English language learners influenced by commodified identities advocated by the private institution?

2) Are private English language learners influenced by commodified identities presented in the textbooks?

3) Are commodified identities suggested persuasively or projected authoritatively to private English language learners?

\section{Methodology}

\subsection{Setting and subjects}

Our site of struggle for the analysis of commodified identities was a private institution and the related variables were English textbooks, six teachers and six learners as our cases. In what follows, we will present the related information on the institution, textbooks, teachers and learners, respectively.

\subsubsection{The institution}

A private institution was chosen as site of our struggle because in such settings there is little control in the choice of teachers and the government has little supervision on such settings. Most of the students who choose English as their major in the University are nurtured in such private schools. To select some representative cases from these private schools, we investigated almost all private language schools in Mashhad (Iran) and found that the private institute of Frough is one of the oldest schools in this area, registered as No. 1623 in 1369 with the permission of Department of Education, Khorasan Razavi province, Iran.

\subsubsection{Textbooks}

The related textbooks of the males were Cambridge English for Schools (CES) and ON Target 2. The females studied In Contact $1 \& 2$.

CES is a five-level course (Beginner, Intermediate, False beginner, Elementary, and Pre-intermediate British English) for young students. The targeted cases' book was CES, book 3, published in 1997 by Andrew Littlejohn and Diana Hicks. It has 160 pages.

On Target 2 written by Diane Pinkley, James E. Purpura in 1999 and printed in the United States has 136 pages and is believed to be a theme-based, integrated skills program for secondary and adult students. It is of the Scott Foresman English series and is appropriate for the intermediate levels. In Contact 1 and 2, the females' course books, are the beginning levels of Scott Foresman English, a theme-based, integrated skills program for secondary and adult students. The writers maintain that Scott Foresman English is a unique and flexible series with multiple entry levels. The book In Contact 1 is written in English language by Barbara R Denman and is published or distributed by Addison Wesley Longman. This particular edition was published on or around 1999-10-1 date. It has 134 numbers of pages of content for use. The book In Contact 2 is related to the Scott Foresman English series and is written in English language by Jane Sturtevant and is published or distributed by Pearson PTR Interactive. This particular edition was published on or around 1999-10-12 date. It has 134 numbers of pages of content for use.

\subsubsection{Teachers}

The teachers chosen were three males and three females. They were all provided teacher insurance for the job security. The method of our teacher selection depended on our learners as our cases. In our large and extended project we met our cases for about four semesters but we observed each teacher for one semester, though we had 
contacts with them during the project as well. We observed a class one semester as a preparatory stage. During our observation, we had many contacts with the teachers through phones, teachers' notes, formal and informal interviews, meeting them in their homes, in the car, in the office and outside the classes. We met them in their classes and we arranged to meet them for interviews in advance. They all were volunteered to take part in the interviews and had signed the written letter which asked them to read the purposes of our research and if possible cooperate with us during the project. The information extracted in the process of interviews both oral and written partly shows the identities of our targeted teachers which will be discussed in the following sections. Some of these teachers' information which is related to our title of investigation on teachers' identities is given below.

We observed each teacher's classes for one full semester but the data collection took four consecutive semesters, about a full year. Their classes (Males and females) were held twice a week, on Tuesday and Thursday (all females' classes), Monday and Wednesday (Case 4), Sunday and Tuesday (Cases $5 \&$ 6). The classes in all four semesters were held from 4: 45 to 6: 15 PM. Each session took 1: 30 minutes. We could record 20 complete sessions (case 1, 10 sessions and case 6, 10 sessions), 36 complete sessions, (Cases 2, 3, \& 5, each case 12 sessions) and 15 complete sessions (Case 4). All the recordings (about 106 hours) were then transcribed for the analysis of the data. The interviews were held four times, one semester before their classroom observation, and at the beginning, in the middle, and at the end of observation. They were given some other ethnographic tools as mentioned too.

Case 1:

Her name was Hedyeh. She was born in Mashhad. She was 29 years old. She was married and had no children. She had started learning English when she was 5 years old. Her native language was Persian and she just knew English as her foreign language. She had a BA and an MA in TEFOL. She had a full time job as an English teacher in Frough institute for 5 years. She was a part-time teacher in some other institutes and Universities as well. In all, she had about 10 years of formal experience of teaching English to students of various proficiency levels from elementary to University students. She was teaching an average of 30 hours in a weak. She had no private English classes.

Case 2:

Her name was Khatereh. She was born in Mashhad. She was 48 years old. She was married and had 3 children, two girls and a boy. Her native language was Persian and she just knew English as her foreign language. She had a BA and an MA in TEFOL. She had a full time job as an English teacher in Frough institute for 7 years. She was a part-time teacher in some other institutes and Universities as well. In all, she had about 13 years of formal experience of teaching English to students of various proficiency levels from elementary to University students. She was teaching an average of 70 hours in a weak including her private English classes.

Case 3:

Her name was Nazanin. She was born in Mashhad. She was 38 years old. She was married and had a boy. Her husband was a teacher teaching Persian literature. She had started learning English when she was 5 or 6 years old. Her native language was Persian and she just knew English as her foreign language. She had a BA in English literature. She was living in Mashhad where she was a full time English teacher in Frough institute for 9 years. She had been a part-time teacher in some other institutes and she had been a full time translator in a company for 9 years. She was still doing this translation job as part time. In all, she had about 15 years of formal experience of teaching English to students of various proficiency levels from elementary to advanced students. She was teaching an average of 50 hours in a weak and 25 hours of translation.

Case 4:

His name was Mohammad. He was 29 years old. He was married and had a little girl. He had started learning English when he was in the guidance school at the age of 12. His native language was Persian and he just knew English as his foreign language. He had a BA in English literature. He was living in Mashhad where he was a full time English teacher in Frough institute for 5 years. In all, he had about 11 years of formal experience of teaching English to students of various proficiency levels from elementary to advanced levels. He was teaching an average of 70 hours in a weak.

Case 5:

His name was Farhad. He was born in Tehran. He was 28 years old. He was married and had no children. He had started learning English when he was 4 years old. His native language was Persian and he just knew English as his foreign language, but he was trying to learn French too. He had a BA in English literature. He was living in 
Mashhad where he was a full time English teacher in Frough institute for 3 years. In all, he had about 6 years experience of teaching English to students of various proficiency levels from elementary to advanced. He was teaching an average of 40 hours in a weak. He had many private English classes.

Case 6:

His name was Shahriyar. He was born in Mashhad. He was 30 years old. He was single. He had started learning English when he was in the guidance school. His native language was Persian and he just knew English as his foreign language. He had a BA in English literature. He was living in Mashhad where he was a full time English teacher in Frough institute for 8 years. He also had private English classes. In all, he had about 12 years experience of teaching English to students of various proficiency levels from elementary to advanced. He was teaching an average of 65 hours in a weak.

\subsubsection{Learners}

Before starting the project, we selected two classes (one male and one female) with 21 learners and focused on 10 learners as our cases. We observed the classes for one semester which took about four months and the observation, language proficiency of the students, learners and their parents' consents for participating in our project resulted in choosing three males and three females as our targeted cases to be studied in the three next semesters. Based on our data gathering, teachers' scores and our tests, the learners' level of proficiency was intermediate. The learners of this institution had a different teacher each semester, but sometimes they had the same teacher who was teaching them for two consecutive semesters, though rarely this happened. In all, these learners experienced six teachers in these three semesters. The male learners had a male teacher and the females had female teachers. Following are some of the learners' information.

Case 1:

His name was Ali. He was 15 years old, a high school student studying experimental science in the second grade. His father was a nurse working in the hospital and his mother was a teacher teaching Persian literature in the high school. He had one brother and two sisters. He was one of the top students in the school with an average of 19.5. His English proficiency was at intermediate level.

Case 2:

His name was Farzad. He was 14 years old, a high school student in the first grade. He was going to choose experimental science in the second grade. His parents were physician. He was the only child in the family. He was one of the top students in the school with an average of 18.90. His English proficiency was at intermediate level.

Case 3:

His name was Mehdi. He was 16 years old, a high school student studying mathematics in the second grade. His father had a free job and his mother was a housewife. He had one brother and one sister. He was one of the top students in the school with an average of 18 . His English proficiency was at intermediate level.

Case 4:

Her name was Narges. She was 15 years old, a high school student studying experimental science in the second grade. Her father was a teacher teaching science in the guidance school and her mother was also a teacher teaching English in the high school. She had one brother and one sister. She was one of the top students in the school with an average of 19.72. Her English proficiency was at intermediate level.

Case 5:

Her name was Maryam. She was 15 years old, a high school student in the first grade. She had not made her mind about her major choice. Her father was a university teacher teaching management in the university and her mother was a teacher teaching accounting in the high school. She had one brother and no sister. She was one of the top students in the school with an average of 18. Her English proficiency was at intermediate level.

Case 6:

Her name was Fatemeh. She was 15 years old, a high school student in the first grade. She was going to study mathematics in the second grade. Her father worked in a hospital and her mother was had a free job selling women clothes. She had one brother and one sister. She was one of the top students in the school with an average of 18.86 . Her English proficiency was at intermediate level. 


\subsection{Instrumentation and procedure}

The data analyzed and the results presented in this article are part of a larger project that aimed to describe the interaction of teachers and textbooks' roles on the identity construction of some private language school learners. Our whole data collection took a long time from 23 September 2010 to 30 September 2011.

To investigate for the existence of commodified identities in the related textbooks we did a content analysis task. Content analysis is a research method for making replicable and valid inferences from data to their context, with the purpose of providing knowledge, new insights, a representation of facts and a practical guide to action (Krippendorff, 1980). Based on the literature review on commodified identity, the typical themes related to commodified identities were extracted and modified by the researchers. In order to come to a common consensus of the typical themes, three independent MA (two) and $\mathrm{PhD}$ (one) raters read the data and marked the saliency of the commodified identities. Graneheim and Lundman (2004) support the value of dialogue among co-researchers to agree the way in which the qualitative data are labeled. The researchers also verified the data in an iterative manner and tested the whole data. Our unit of analysis was a combination of discrete units and discourse. The reason for including discourse as one of our unit of analysis in the content analysis of the textbooks was inspired by Bakhtin's theoretical framework which shows that the unit of analysis should be the whole context. Oliva (2000), Matusov (2007) and Tihanov (2000) also advocate discourse as the unit of analysis for the dialogical methodology.

After reading the whole content, the data were classified into three categories of cultural topics, cultural activities and cultural names. In each category we searched for the existence of commodified identities. As Cavanagh (1997) notes, the purpose of creating categories is to provide a means of describing the phenomenon, to increase understanding and to generate knowledge. Credibility of research findings also deals with how well the categories cover the data (Graneheim \& Lundman 2004).

To find the related cultural topics, first we looked at the content or outline of the book presented at the beginning pages of each book. Then, we had a micro look at each lesson and searched for the related topics. We wrote the page numbers too. Moreover, in this section, following Phillipson (1992), we were supposed to determine whether the topic was related to the English or American Culture (we called it Native), or to Other Cultures, including Iran, if given (we called it Alien). If the country was mentioned, wet tried to mention it as well, or if it was not clear to which category the topic may fall, we had to write Neutral. In other sections (Cultural activities, and Cultural Names) we did the same. Putting the data in the appropriate categories was a challenging task as Dey (1993) mentions, when formulating categories, the researcher comes to a decision, through interpretation, as to which things to put in the same category.

The second category was cultural activities. They were like cultural topics, but we had a more detailed analysis within the lessons (e.g. warm-up, grammar parts, exercises, Reading, Speaking, and Writing (listening parts were excluded, but if there were some written data related to the listening parts and it was related to a particular cultural type, we had to mention them. Furthermore, in the cultural activities part, we determined whether each activity presented is Native, Alien, or Neutral and if it was Authoritative, or Persuasive.

The third category was cultural names. In this section, we tried to find all the names (names of persons, objects, jobs, etc., whether abstract or concrete) related to commodified identities, in all parts of each lesson. In the cultural names part, we also determined whether each name presented was Native, Alien, or Neutral. After the analysis of the whole data, we counted the numbers of each category and put the frequency of the numbers in the Tables.

Based on our ethnographic tools including teachers' interviews, teachers' journals and notes, audio and sometimes videotaped classroom observations of each teacher, and the participant-observer's research journal, we tried to search for the commodified identities in the whole data of our teachers. We used both semi-structured interview and unstructured interviews (Ellis \& Haugan, 1997; Fontana \& Frey, 2005). Researchers making use of unstructured interviews often hold a constructivist point of view of social reality (Denzin, 1989). As the purpose of the interviews was reconstructing teachers' identities and not understanding the proficiency level of the teachers, the interviews were held both in English and Persian. Unstructured interviews are governed by the cultural conventions of the research setting, which requires that the researcher can understand the interviewees' language and, further, its meanings in the specific cultural context of the research setting (Fife, 2005). The Persian interviews then were translated into English. We were given permission to tape the interviews and they signed an agreement that allowed us to use the transcribed material in our project. To observe codes of ethics in research, however, the names are fictitious. The questions were open ended questions and let them talk freely about their understanding of the commodified identities, the importance they give to these types of identities and their influence on the context of language learning and teaching. In our targeted larger project, however, we asked them many other questions 
regarding some types of identities. But, our focus in the present article is to look at the data to investigate the influence of commodified identities. Due to the large corpus of our data (about 30 hours formal and informal interviews with teachers), we tried to extract only the parts related to our focal commodified identities. Besides interviews, the occurrence of commodified identities was explored in the remaining data including our other ethnographic tools. We try to show and clarify them by giving some instances, though it is difficult to present them all. It is sometimes difficult to give a thorough presentation of the results of qualitative research in a format that is compatible with the space and word limitations in professional journals (Polit \& Beck, 2004). The same procedure with the same ethnographic tools was done for the learners. We will give the appropriate instances relating to the commodified identities of the learners too.

\section{Results and discussions}

\subsection{Textbooks commodified identities}

The content analysis of all textbooks shows that commodified identities are not extensively promoted. In the females' textbooks, the number of commodified cultural topics is just seven topics in the two books, the number of commodified cultural names is 30 and there are 17 commodified cultural activities. The discourse types related to sub-categories of neutral, native, and alien are mostly neutral (See Table 1). And the authoritative/persuasive discourse is almost the same. The males' textbooks have almost the same frequencies (See Table 2). It may seem that the authors are not promoting the commodified identities directly and though we are in the 'post-industrial late modernity', the books at least directly do not show the projection of this type of identity. The presentation of commodified activities is also more persuasive than authoritative in all the books. It means that the authors are not going to present the content by force. Perhaps they are going to present the content in English. And English is considered for them as a commodity. More specifically, 'what is included and excluded in textbooks really signal more profound political, economic and cultural relations and histories', and hence, a 'particular construction of reality' (Apple and Christian-Smith, 1991, p. 3). Moreover, the textbook is just one variable and the content is regarded static and it should be combined with other variables, such as teachers and learners' roles.

Table 1: The content analysis of textbooks (In Contact $1 \& 2$ ) (females) based on cultural topics, cultural names and cultural activities

\begin{tabular}{|c|c|c|c|c|c|c|c|c|c|c|c|c|c|}
\hline Cultural Topics & N. & DT & N. & Cultural Names & $\mathrm{N}$. & DT & N. & $\begin{array}{l}\text { Cultural } \\
\text { Activities }\end{array}$ & N. & DT & N. & DT & $\mathrm{N}$. \\
\hline \multirow[t]{3}{*}{ Commodified } & 7 & $\mathrm{Na}$. & 1 & Commodified & 30 & $\mathrm{Na}$. & 1 & Commodified & 17 & A. & 7 & $\mathrm{Na}$. & 5 \\
\hline & & AL. & 2 & & & AL. & 2 & & & P. & 10 & AL. & 2 \\
\hline & & NE. & 4 & & & NE. & 27 & & & & & NE. & 10 \\
\hline
\end{tabular}

Note 1: N. Stands for Number, DT for Discourse Type, NA. for Native, AL. for Alien, NE. for Neutral, A for Authoritative, P. for Persuasive.

Table 2: The content analysis of textbooks (CES \& On Target 2) (males) based on cultural topics, cultural names and cultural activities (all lessons)

\begin{tabular}{|c|c|c|c|c|c|c|c|c|c|c|c|c|c|}
\hline $\begin{array}{l}\text { Cultural } \\
\text { Topics }\end{array}$ & N. & DT & $\mathrm{N}$. & $\begin{array}{l}\text { Cultural } \\
\text { Names }\end{array}$ & $\mathrm{N}$. & DT & N. & $\begin{array}{l}\text { Cultural } \\
\text { Activities }\end{array}$ & $\mathrm{N}$. & DT & $\mathrm{N}$. & DT & $\mathrm{N}$ \\
\hline \multirow[t]{3}{*}{ Commodified } & 4 & $\mathrm{Na}$. & 2 & Commodified & 46 & $\mathrm{Na}$. & 0 & Commodified & 33 & A. & 11 & $\mathrm{Na}$. & 10 \\
\hline & & AL. & 0 & & & AL. & 0 & & & P. & 22 & AL. & 2 \\
\hline & & NE. & 2 & & & NE. & 46 & & & & & NE. & 21 \\
\hline
\end{tabular}

\subsection{Teachers commodified identities}

They all but considered the private institution as a commodity place which is linked to learning English and compared it with public schools which are not appropriate places for learning English. They all but regarded learning English as a commodity which made them connect to the outside world and they could have access to other facilities symbolically or materially. They were almost all busy teaching English and teaching English was a capital for them.

English as commodity creates a situation for linking to other commodities as well. For example, the teachers had a mobile cell phone and they all had some English dictionaries installed in them. But, it seems that these teachers had at their disposal some simple facilities and there was no force or motivation to consume English related materials. This was true for their learners as well. Here are some extracts: 
Case 1 (Hedyeh):

- Let's see. For example in our classes we simply use a white board and a marker except the sessions which we use movies in our classes. Only we bring the cassette player with cassettes to the class when we have listening practice. It works well. The white board and the eraser and the marker which are used are ordinary and nothing special.

- What do students need to have?

- Textbook, the book, CD and dictionary.

The role of the institution was also important in shaping the commodified identities of the learners and teachers. There were some cases in which the institution had forbidden the use of mobile in the classes. But, this rule was not obeyed by all the teachers and learners.

Case 2 (Khatereh):

- What if they have dictionaries in their cell phones?

- $\quad$ They [the institution] say students have to buy them. At the meeting which was held in the holiday they asked us not to let them use their cell phones in the class.

It is noteworthy that we found that the institution had a private book store and the learners were persuaded to buy their items from their store.

Case 1 (Hedyeh):

- Do you let them to use-dictionary on their mobile?

- $\quad$ Yes, the aim is learning to use the dictionary for checking the meaning of the words.

Case 5 (Farhad):

- $\quad$ Are your students forced to buy dictionary?

- $\quad$ No it is not a force.

- Someone's mobile has a dictionary, you let him use it?

- Yes, I would.

In their routine life, however, there were different feedbacks from the teachers toward the consumerism world, which directly and indirectly shows their sense of commodified identities:

Case 2 (Khatereh):

- Do you go shopping?

- $\quad$ If it it's needed, but I don't buy anything I see.

- What's your opinion about this slogan? I consume, therefore I am.

- I think it is better....Well, it's a materialistic attitude toward people and it's true.

And we asked an unreal question from Khatereh putting her into an imaginary situation:

- What would you do if you own a lot of money?

- $\quad$ I would buy a villa and invest.

- Then what?

- $\quad$ Nothing, but I like to invest more... and I would migrate through investment to Canada.

Case 3 (Nazanin):

- $\quad$ Do you think it's possible to live without a cell phone?

- Yes.

- Do you like shopping?

- $\quad$ No. Well, I'd like to..., no.

- Have you ever heard some statements like: 'I think, so I exist', 'I consume, so I am?

- $\quad$ I do apologize, but it's silly. 
- Do you disagree with consumerism?

Case 5 (Farhad):

- Well... I want to tell you something but you know in commercial, today I suppose to break myself because I was so much concerned that you can actually forget me or you can actually lose the way... I've thought probably living without mobiles, it's gonna be such a hard job but I did it. I am feeling so much relieved and I wish I could drop it away for a permanent time but I can't. I need it. I'm alike. I did it .It has pretty much use.

Case 6 (Shahriyar):

- I have no time to buy and think about, you know, these things. What is important for me is teaching and checking the students' progress.

It seems that these teachers have different ideas regarding the concept of commodified identities. On the one hand, like textbooks' role, this shows the importance of teachers' roles in the context of language teaching. Those teachers who believe or disbelieve in consumerism may shape the identities of the learners in one way or another. On the other hand, it seems that the teachers' identities are changing and when they are put in some other context of situation, for example, an imaginary context, they act and respond differently.

Moreover, the analysis of the whole data of Hedyeh, for instance, shows that she considered having commodity in life as a symbolic value and directly and indirectly showed some signs of commodification in her actions. She was not very busy as she was afforded by the family and among the targeted teachers she had a normal academic life. In contrast to other teacher's careers, she didn't have some private classes.

- Why do you teach? First tell me from the financial aspect.

- Financially, I don't need to teach.

- This doesn't satisfy you at all. It means.......

- Since we were girls, my father cared about us even more than our brothers. For example, since I was a student in another city, they would give me more money..... They cared me lot.

- So, your purpose is not a financial matter.

- No. It's not a financial matter. I myself like to be independent and earn money to buy something.

Sometimes she compared her 'self' with her classmate' who was her friend and considered her own educational assets as her 'cultural capital'.

- They have several houses and villas. Secondly, they are better than us from the point of social class even the way they live. When you go to their house, it is so large. It has several stairs. In their points of view, I belong to the average class of society, but educationally, we are in the same range. Even in some aspects, I am better than her. For instance, I could defend my thesis sooner and she did it with some more delay.

Generally, the teachers' classroom observation did not reveal the occurrence of any highlighted commodified identities. In all, they wore simple formal clothes as far as our classroom observation revealed. The colors, of course, were different, which is not related to our present discussion. Males wore more colorful clothes rather than dark clothes compared with the female teachers. They didn't preach consumerism and they didn't show if they were for or against it. Probably, they didn't care about it. They may have had some financial problems as the data showed that they were almost very busy teachers. Or, the content of the textbooks did not provide a suitable context for the discussion of commodified identities. Or, as some revealed, they were by nature not for the consumerism world. They defined their 'selves' in other ways. There was nothing revealing in their notes regarding the commodified identities as well. Following are also some extracts from the teachers' recordings which show the traces of commodified identities, which were not much highlighted. They were all but emerged in the context as it was backed by the content of the textbooks. In other words, the teacher themselves did not start conversations on commodities.

Hedyeh:

- So, these writings are some information, ok? They are ads, ads? (Students in Persian say, Agahi [ads], aha, the short form of advertisement, ok? By reading newspaper, by watching TV, listening to radio, yes? Now, here are some ads, get ready for a good job.

Khatereh:

- Why did Vera's first albums sell so well? Because...Do you know the answer? Next. 
- Because, Vera's first album sold more because it sells 4000000 copies.

- No, no, this is not the answer. You.

- Because, Vera worked bard to promote it.

- Aha. Because, Vera worked hard to promote it. F.

Farhad:

- They are standard? What should we do? We should decrease the price of the book. But I think the books are not pretty expensive ....are expensive? In expensive countries?

- No.

- You can buy them.

- What else?

- Download them. We can borrow it.

The teachers were also different and in the process of identity construction for that matter in regard to the discourse type of identity projection. For instance, the analysis of the whole data of cases 1 and 3, 5, and 6 showed that they were almost not authoritative by nature. They were observed, however, just in the educational context. Case 2 acted based on the authoritative rules of the institution. The learners had to buy the English books, CDs, and the related English materials from the library belonged to the institution. Case 4 (Mohammad) was more authoritative. It was probably, among other factors, due to his noisy and overcrowded class. His students were naughty and he couldn't sometimes control the class. Following are two instances of his authoritative nature in regard to commodified identities:

Mohammad:

- $\quad$ [interview]: Are the students bound to buy dictionary?

- Yes, sometimes, I'll force them to buy one.

- [Classroom]: Where is your dictionary?

- .... ديكثنريم [My dictionary?]

- How many students, don't have dictionary? Raise your hand.

- Have or don't have?

- Don't have. Don't have. Don't have. Raise your hand. Zare, Bagheri, You? Ok. Amoozgar. You? You don't have it? Negative mark.

- $\quad$ No, no.

- I won't, I won't accept any excuse. No excuse. Ok? This session, I have to give you negative marks.

- كفين ديكثنرى بيارين [You told us to get dictionary?]

- Those students, those students who actually, listen to me... listen to me guys. Those students who didn't have dictionary this, Ammm... this session, you have to get it for next session, otherwise, what happen? Another negative mark, ha?

\subsection{Learners commodified identities}

Though the total number of commodified identities presented in the textbooks in terms of topics, names and activities was not a large enough to set a ground for affecting learners' ideology, they were directly and indirectly affected by various factors. One of the factors which can be considered as an outside factor was the role of the institution in planning a set of rules to be obeyed by all the staff including teachers and learners. The teachers and the learners had no choice in their English materials. The teachers were told to introduce the prescribed books mentioned and they were told that they must order the students to buy the books from their own library which was established in the institution's yard. The interview with the learners, our cases, showed that they all have bought the books, CDs, and dictionaries from the institution's library. However, in this setting, there was not so much consumerism in terms of buying and selling English materials. The very English language created a competitive situation for all the families that they sent their children to these schools and then learning English brought about many other changes in their life. The private school spent a lot of money for advertisement. English was considered a capital for them. They 
were more influenced by the school in contrast to the contents of the textbooks.

The textbooks' contents as showed highlighted little amount of commodified identities, but the learners were affected by links created by English learning. Ali, for instance, was a fan of car magazine and was impressed by the discourse related to his favorites. He said that English learning causes him to buy English books and English cartoons and he said that they have not satellite to get access to foreign channels:

- What do you do in your spare time?

- I come back home from school at noon and I go to English classes every other days. I watch movies. We don't have satellite. I'm interested in historical movies and English cartoons such as ice age.

- Do you read books other than school books?

- No, but I love car magazines.

- What do you have in your room related to English language?

- $\quad$ Books, PC and TV.

Following are more instances of such links caused by the English language.

Farzad:

- What do you have related to English learning?

- A computer, cell phone, storybook, language books.

- Do you have a dictionary in your cell phone?

- Persian to English dictionary, English to Persian dictionary and stories.

- What other facilities do you have for learning English?

- Books, storybooks, dictionary, software.

Mehdi:

- What do you have as your English properties?

- A dictionary and books.

- Do you have a computer too?

- Computer? Yes.

- Do you surf the English sites too, or just Persian sites?

- Yes, usually I search in English, for example, if I want to search about some digital thing, I search in English.

- I usually search some catalogues of the cell phones and computers and the information and something new.

- Do you have a dictionary now?

- Not at the moment.

- No, I mean in your document case.

- Well, I carry that most of the time there.

- Do you have a dictionary in your cell phone too?

- No.

- Why not? Aren't you into computers and cell phones and why not?

- You know, 'cause this cell phone with me now isn't capable of having a dictionary, but I can do it with my other cell phone.

- No, I don’t mean just now, I mean generally, do you have a dictionary installed on your cell phone?

- Yes

Narges:

- I didn't watch TV much before .......MBC Persia ...PMC and Etc. .....and satellite channels ....satellite is not ... it only has music and ... 
- Which channels could be on satellite and you used to improve your English so far?

- Smile of child.

- Is that the name?

- Yeah.

- $\quad$ Or is it the program's name?

- It is its name ...it is for children ....but when they talk I understand ...but I seldom watch it ....I am not like following the shows ....I watch movies more....

- How much time do you spend listening to English?

- $\quad$ For example, I listen to English music with my mobile.

Maryam:

- Don't you have satellite?

- $\quad$ Not satellite, but I watch English movies.

- I have a lot of English movies.

- For example?

- Naverinia, High school musical 1, 2, 3, Spider man, Mummy, Crisis, and, hmm... Avatar and Alice in Wonderland, also 2010.

Fatemeh:

- What about computer?

- Yes, I have.

- You know how to work with it?

- Yes.

- How much?

- In a way that I could do my work.

- What kind of work?

- For example, if I want to do a research or use internet.

- What do you do with internet?

- I usually use it for doing researches or for free study or if I want to know about something and if I want to gather information.

- Do you search in English or in Persian? I mean the language.

- Language?

- For example if you want to search something, do you type it in Persian?

- Yes.

- How much internet influences your English learning?

- For example, when I listen to some English music, I use internet and I search and find the lyric of that music and then when I listen to it again I understand it better.

- Do you have English movies?

- Yes.

- Do you watch them?

- Yes.

- What kind of movies? Can you talk about them?

- You mean the subject of that?

- Yes. 
- Family movies, horror ones. I like horror movies.

- In English or Persian?

- No. For example, in English with Persian subtitle, or in Persian with English subtitle.

- How much these movies help your English learning?

- It really helps, for example...

- It helps you in what?

- Listening.

All the above extracts show the power of English in connecting these learners to many other areas of social life. In fact, English can be a center of commodification for them and other sources can sell their objects directly or indirectly. This is in line with the ideas of Bourdieu (1986), Phillipson (1992) and Heller (1999) in that commodification draws on a larger theory of the political economics of language, which basically objectifies and evaluates languages in relation to the goods that they can be exchanged for.

In a personality questionnaire presented in their books, $\mathrm{O}$ target 2 (p. 44), three females responses were affected by the content of the book which was about commodified identities. Some questions asked were: 1 . what do you most look forward to doing? 2. What can you easily imagine yourself doing? They answer these three learners selected were 'getting a high-paying job', and 'buying a large home'. It may be argued that they may have been affected by many other factors, but the point is that the content can reinforce their identities projected and repeated by the textbooks. Moreover, they had some other choices to choose from such as 'making friend', 'having a happy home life', 'discovering who I am' for question number 1, and 'falling in love', 'living in the country', 'changing my career', for question number 2. There were some other instances in different parts of the books which showed the learners' influences.

We also gave them some discourse completion tests and some open ended questions after each semester to find if they are affected by the topics, names, and activities of the books presented through the English Language. One of the commodified identities open questions was the description of a favorite home. The females in their book, In Contact 2, Unit 3, (p. 21) had a lesson called 'Where we live'. This lesson advertises having a house with many facilities such as living room, kitchen, bedroom, bathroom, dining room, etc. The exercises also reinforced having a big house, etc. The analysis of their responses showed that they had repeated many characteristics of the house mentioned in the book.

A mentioned before, the discourse type projected in the book was mostly persuasive. The authors of the book tried to present the data persuasively and they know that the contents serve cognitive foods. Based on these little samples, we may not be able to claim that learners are undergoing cultural hybridity (Bhabha, 1994), but inspired by Bakhtin (1981, p. 360), we believe that 'such unconscious hybrids have been at the same time profoundly productive historically: they are pregnant with potential for new world views, with new 'internal forms' for perceiving the world.

\section{Concluding remarks}

It seems that commodified identities are contextualized, historical and dynamic. The extent of their existence and their promotion depends upon many variables including textbooks, teachers and learners, among probably many other variables which are not related to the present study. The commodified identities were not very much highlighted in the books we analyzed. But, this does not mean that the role of textbooks should be ignored. Even the absence of the commodified identities in the textbooks had some influences on the teachers and learners' discourse. There were little discussion of commodified identities by the teachers and learners in the classroom context as they were not provided by these cognitive foods. We found, however, some traces of commodity discourse which were again promoted and speeded up by the content of the textbooks. This shows the importance of textbooks' contents directly or indirectly. As Byram (1997, p. 22-29) maintains 'textbook contents are value-laden wherever they are produced in the world'. Teachers' roles, on the other hand, were another factor which was investigated in this study. It was linked with the textbooks' role in the sense that when the content was projecting commodified identities they had to focus and promote such identities as well. The discourse types associated with projecting the identities depended on the characteristics of the teachers and the social context they were living in. Most of them had no desire to preach consumerism directly, but their teaching English was the central tool which resulted in connecting learners to other areas of social capital. They themselves were in the process of identities formation and deconstruction depending on the context of situation. And, finally learners were affected by the contents of the textbooks, the institution's 
authority forcing them to buy the English learning materials, and some teachers' coercive discourse which compelled them or motivated them to be consumers of the English language.

This study, however, needs to be contextualized by many other researchers, who account for analyzing a larger population, take into account many other types of identities, and consider different types of schools with many other books. Due to the space problem, we tried to present a small data to clarify and discuss our arguments by triangulation of the data. This cultural case study may open new horizons for other cultural studies and may have direct pedagogical implications for those involving in the language teaching fields such as English learners, teachers, syllabus designers, policy makers, and more particularly for those who see culture as a seminal part of a country' identity.

\section{References}

Apple M., \& Christian-Smith, L. (1991). The politics of the textbook. London: Routledge.

Ashcroft, B., Griffiths, G., \& Tiffin, G. (2000) ( $2^{\text {nd }}$ Ed.). Key concepts in post-colonial studies. London: Routledge.

Bakhtin, M. M. (1981). The dialogic imagination. Austin: University of Texas Press.

Baudrillard, J. (1998). The consumer society: Myth and structures. (Ttrans. C. Turner). London: Sage.

Bauman, Z. (2004). Identity. Cambridge: Polity Press.

Benwell, B. M., \& Stokoe, E. H. (2006). Discourse and identity. Edinburgh University Press.

Bhabha, H. K. (1994). The location of culture. London: Routledge.

Bourdieu, P. (1984). Distinction: A social critique of the judgment of taste. London: Routledge.

Bourdieu, P. (1986). The forms of capital. In J. G. Richardson (Ed.), Handbook of Theory and Research for the Sociology of Education (pp. 241-58). New York: Greenwood Press.

Bourdieu, P., \& Passeron, J. C. (1977). Reproduction in education, society and culture. (Trans. Richard Nice \& Tom Bottommore). London: Sage.

Bowers, C. (2000). Let them eat data. University of Georgia Press: Athens, Greece.

Byram, M. (1997). Teaching and assessing intercultural communicative competence. Clevedon, Multilingual Matters.

Campbell, C. (1987). The romantic ethic and the spirit of modern consumerism. Oxford: Blackwell.

Cavanagh, S. (1997). Content analysis: concepts, methods and applications. Nurse Researcher, 4, 5-16.

Cindy, C., Jonah, B., \& Leaf, V. B. (2012). Identifiable but not identical: Combining social identity and uniqueness motives in choice, Journal of Consumer Research, 39, (3), 561-573.

Corrigan, P. (1997). The sociology of consumption: An introduction. London: Sage.

de Saussure, F. (1960). Course in general linguistics (Ed. C. Bally and A. Sechehaye) (Trans. W. Baskin). London: Peter Owen.

Delpit, L. (1995). Other people's children: Cultural conflict in the classroom. New York: New Press.

Denzin, N. K. (1989). The research act: A theoretical introduction to sociological methods (3rd Ed.). Chicago: Aldine.

Dey I. (1993). Qualitative data analysis: A user-friendly guide for social scientists. Routledge, London.

Douglas, M., \& Isherwood, B. (1979). The world of goods: Towards anthropology of consumption. London: Allen Lane.

Ellis, D., \& Haugan, M. (1997). Modeling the information seeking patterns of engineers and research scientists in an industrial environment. Journal of Documentation, 53(4), 384-403. http://dx.doi.org/10.1108/EUM0000000007204

Fairclough, N. (1992). Discourse and social change. Cambridge: Polity Press

Featherstone, M., \& Burrows, R. (Eds.). (1995). Cyberspace/cyberbodies/cyberpunk: Cultures of technological embodiment. London: Sage.

Fife, W. (2005). Doing fieldwork: Ethnographic methods for research in developing countries and beyond. New York: Palgrave Macmillan. 
Fiske, J. (1989). Understanding popular culture. London: Routledge.

Fontana, A., \& Frey, J. H. (2005). The interview: From neutral stance to political involvement. In Denzin, N. K., \& Lincoln, Y. S. (Eds.), The Sage Handbook of Qualitative Research. (3rd Ed.) (pp, 695-728). Thousand Oaks, CA: Sage.

Frost, A. D. (2010). Marketing the academy: A theoretical analysis of consumption, identity, and the branding of the contemporary universities. Master thesis. Retrieved from www.mta.ca/communications/frost-thesis_v19FINAL.pdf.

Gee, J. P. (1996). Social linguistics and literacies: Ideology in discourses (2nd Ed.). Bristol, PA: Falmer Press.

Gee, J. P. (2011). An introduction to discourse analysis: Theory and method. New York, NY: Routledge.

Giddens, A. (1991). Modernity and self-identity. Cambridge: Polity Press.

Graneheim, U.H., \& Lundman, B. (2004). Qualitative content analysis in nursing research: Concepts, procedures and measures to achieve trustworthiness. Nurse Education Today, 24, 105-112. http://dx.doi.org/10.1016/j.nedt.2003.10.001

Hall, S. (1992). The question of cultural identity. In S. Hall, D. Held \& T. McGrew (Eds.), Modernity and Its Futures (pp. 273-316). Cambridge, Polity Press.

Hamouda, M. (2012). Postmodernism and consumer psychology: Transformation or break? International Journal of Academic Research in Business and Social Sciences January, 2(1), 96-117.

Heller, M. (1999). Alternative ideologies of 'la francophonie'. Journal of Sociolinguistics, 3(3), 336-59. http://dx.doi.org/10.1111/1467-9481.00082

Kaela, J. (2011). Shopping for identity: Articulations of gender, race and class by critical consumers. Social Identities, 17(3), 321-335. http://dx.doi.org/10.1080/13504630.2011.570972

Keat, R., Whitely, N., \& Abercrombie, N. (Eds.). (1994). The authority of the consumer. London: Routledge.

Krippendorff, K. (1980). Content analysis: An introduction to its methodology. Sage Publications. Newbury Park.

Matusov, E. (2007). Applying Bakhtin scholarship on discourse in education: A critical review essay. Educational Theory, 57(2), 215-237. http://dx.doi.org/10.1111/j.1741-5446.2007.00253.x

Miles, S. (1998). Consumerism: As a way of life. London: Sage.

Oliva, M. O. (2000). Shifting landscapes/Shifting langue: Qualitative research from the in between. Qualitative Inquiry, 6(33), 33-54. http://dx.doi.org/10.1177/107780040000600103

Phillipson, R. (1992). Linguistic imperialism. Oxford: Oxford University Press.

Polit D. F., \&, Beck, C.T. (2004). Nursing research: Principles and methods. Lippincott Williams \& Wilkins, Philadelphia, PA.

Singh, M., \& Han, J. (2008). The Commoditization of English and the Bologna process: Global products and services, exchange mechanisms and trans-national labor. In P. K. W. Tan and R. Rubdy (Eds.), Language as Commodity: Global Structures, Local Marketplaces (204-224). Cornwall: London.

Talbot, M. (1995). A synthetic sisterhood: False friends in a teenage magazine. In K. Hall and M. Bucholtz (Eds.), Gender Articulated: Language and the Socially Constructed Self(143-65). London: Routledge.

Tan, P. K. W. (2008). The English language as a commodity in Malaysia: The view through the medium-of-instruction debate. In P. K. W. Tan and R. Rubdy (Eds.), Language as Commodity: Global Structures, Local Marketplaces (106-121). Cornwall: London.

Tihanov, G. (2000). The master and the slave: Lukacs, Bakhtin, and the ideas of their time. Oxford and New York: Oxford University Press.

Veblen, T. (1899). The theory of the leisure class: An economic study in the evolution of institutions. New York: Macmillan.

Wächter, B. (2004). The Bologna process. European Journal of Education, 39(3), 265-73.

Zeynep, A., \& Craig, J. T. (2011). Demythologizing Consumption Practices: How Consumers Protect Their FieldDependent Identity Investments from Devaluing Marketplace Myths, Journal of Consumer Research, 37(5), 791-806. 